\title{
ANALISIS EVALUASI PENERAPAN SISTEM INFORMASI PENGOLAHAN NILAI PADA KURIKULUM 2013 DENGAN METODE TAM
}

\author{
Ummi Khalifah $^{1}$, Nur Nawaningtyas Pusparini ${ }^{2}$, Oki Kusmawan ${ }^{3}$ \\ ${ }^{1,2}$ Teknik Informatika, ${ }^{3} \mathrm{Ilmu}$ Komputer \\ ${ }^{1,2}$ Sekolah Tinggi Manajemen Informatika dan Komputer (STMIK) Widuri \\ ${ }^{3}$ Universitas Budi Luhur Jakarta, Indonesia \\ Correspondence email: tyaspusparini@kampuswiduri.ac.id
}

Article history: $\quad$ Submission date: Nov 10, 2020 Revised date: Nov 17, $2020 \quad$ Accepted date: Nov 26, 2020

\begin{abstract}
The purpose of the 2013 Curriculum which is regulated by the Regulation of the Minister of Education and Culture Number 67 of 2013 is to prepare Indonesian people to have the ability to be faithful, productive, creative, innovative, affective and able to contribute to life. In processing values in the 2013 Curriculum, there are 3 (three) assessments such as assessment of students' attitudes, assessment of knowledge, assessment of skills, this is expected to form student character from an early age. However, in the application of the processing, there are several obstacles including some basic competencies that need to be inputted and this takes a long time, besides that the teacher's lack of understanding of IT becomes a challenge when the teacher wants to input data into the system. In the study, the authors used data collection methods such as observation, interviews, questionnaires and literature study. Meanwhile, to evaluate the value processing system using the Technology Acceptance Model (TAM) with 4 parameters such as Perceived Ease of Use, Perceived Usefulness, Attitude Toward using, Behavioral Intention To Use. This method results in showing users believe that the value processing information system with the 2013 curriculum can provide benefits and uses. indicates the user feels confident enough that the system being used is easier to use and operate. shows the great curiosity of the user to use the system. indicates that there is a desire to continue using the system and there is a desire to influence other users to use the system.
\end{abstract}

Keywords: Value Processing, TAM, Curriculum 2013, Evaluation.

\begin{abstract}
ABSTRAK
Tujuan dari Kurikulum 2013 yang diatur oleh Peraturan Menteri Pendidikan dan Kebudayaan Nomor 67 Tahun 2013 adalah mempersiapkan manusia Indonesia untuk memiliki kemampuan yang beriman, produktif, kreatif, inovatif, afektif dan dapat berkontribusi untuk kehidupan. Dalam pengolahan nilai pada Kurikulum 2013 terdapat 3 (tiga) penilaian seperti penilaian sikap peserta didik, penilaian pengetahuan, penilaian ketrampilan, hal ini diharap dapat membentuk karakter siswa sejak dini. Namun di dalam penerapan pengolahannya terdapat beberapa kendala diantaranya beberapa kompetensi dasar harus diinputkan datanya dan hal ini membutuhkan waktu yang tidak sebentar, selain itu kurangnya pemahaman guru mengenai IT menjadi tantangan tersendiri ketika guru hendak akan menginput data ke dalam sistem. Pada penelitian, penulis menggunakan metode pengumpulan data seperti observasi, wawancara, kuesioner dan studi pustaka. Sedangkan untuk mengevaluasi sistem pengolahan nilai menggunakan Technology Acceptance Model (TAM) dengan 4 parameter seperti Perceived Ease of Use, Perceived Usefulness, Attitute Toward using, Behavioral Intention To Use. Metode ini menghasilkan menunjukkan pengguna percaya bahwa adanya sistem informasi pengolahan nilai dengan kurikulum 2013 dapat memberikan manfaat dan kegunaan. menunjukkan pengguna merasa cukup meyakini bahwa sistem yang digunakan lebih mudah digunakan dan dioperasikan. menunjukkan keingintahuan yang besar dari pengguna untuk menggunakan sistem. menunjukkan bahwa adanya keinginan untuk tetap menggunakan sistem dan ada keinginan untuk mempengaruhi pengguna lain untuk menggunakan sistem.
\end{abstract}

Kata Kunci: Pengolahan Nilai, TAM, Kurikulum 2013, Evaluasi. 


\section{PENDAHULUAN}

Kurikulum 2013 merupakan kurikulum yang sudah diatur oleh Peraturan Menteri Pendidikan dan Kebudayaan Nomor 67 Tahun 2013. Pada Peraturan Menteri tersebut membahas tentang Kerangka Dasar dan Struktur Kurikulum Sekolah Dasar/Madrasah Ibdiyah. Kurikulum 2013 dikembangkan berdasarkan tantangan faktor eksternal dan tantangan internal. Pada tantangan internal dikaitkan dengan tuntunan pendidikan dan tantangan internal. Faktor eksternal meliputi arus globalisasi dan perkembangan teknologi informasi serta perkembangan pendidikan tingkat Internasional (Astuti et al., 2019).

Dalam pembelajaran dan pengolahan nilai menggunakan kurikulum 2013 dalam penggunaannya ada kelebihan yang di dapat tetapi ada juga masalah yang di hadapi oleh guru ataupun peserta didik itu sendiri. Dengan adanya penilaian yang bervariasi dapat membentuk karakter siswa sejak dini terlebih dengan dibantu peran teknologi sehingga peserta didik lebih cepat memahami apa yang disampaikan oleh guru (Astuti et al., 2019).

Berdasarkan hasil wawancara yang dilakukan, sistem pengolahan nilai dengan kurikulum 2013 selama penerapannya dirasa memudahkan para guru, namun pada proses penginputan datanya membutuhkan waktu yang tidak sebentar karena terbentuk dari beberapa kompetensi dasar, selain itu kurangnya pemahaman IT dari para guru sehingga dalam proses pengolahan nilai guru membutuhkan waktu yang lebih banyak untuk menyelesaikannya (Budiyantara et al., 2020).

Lebih lanjut diketahui bahwa dengan sistem pengolahan nilai menggunakan kurikulum 2013 terdapat beberapa kendala seperti banyaknya administrasi penilaian yang harus diselesaikan dan salah satunya mengenai penilaian pada aspek pengetahuan, selain itu guru harus menyelesaikan banyaknya nilai dalam satu mata pelajaran (Abidin et al., 2013).

Berbeda ketika menggunakan Kurikulum Tingkat Satuan Pendidikan (KTSP) guru hanya mengambil penilaian seperti nilai harian, nilai tugas, nilai PTS dan nilai PAS serta pada sistem pembelajarannya masih fokus pada satu mata pelajaran dan penilaian belum terbagi - bagi atas Kompetensi Dasar (KD) jadi lebih mudah untuk pengolahan nilainya. Untuk pengolahan nilai dengan menggunakan Kurikulum 2013 saat ini sudah tersistem dengan adanya kemajuan teknologi, peran teknologi di sini sudah terlibat. Berbeda dengan Kurikulum Tingkat Satuan Pendidikan (KTSP) yang masih banyak melakukan penulisan mengggunakan kertas (Sujai et al., 2016).

Technology Acceptance Model (TAM) adalah adaptasi dari Theory of Reasoned Action (TRA). TAM digunakan untuk mengukur kesuksesan dari penerapan sistem informasi berdasarkan keinginan pengguna dalam menggunakan sistem informasi tersebut (Ramadhani \& Monalisa, 2017).

Dari penelitian sebelumnya menjelaskan bahwa TAM is a model to measure the behavior factors of technology acceptance, the first is perceives usefulness, and the second is perceived ease of use. Perceives ease is a condition where the user wants to use if the system s easy to use by him, while the perception of usability is a condition where the user wants to use the system if it is useful for him. With the ease of the system understood by the user then a rises the desire to use the system and the more often the user uses a system it shows the system is beneficial to him, then it can be said the user can accept the system (Wiliani et al., 2020).

Jadi dapat diartikan bahwa TAM merupakan model untuk mengukur faktor perilaku dari penerimaan teknologi, dimana yang pertama adalah persepsi kegunaan dan kedua adalah persepsi kemudahan penggunaan. Persepsi kemudahan merupakan kondisi dimana pengguna ingin menggunakan sistem tersebut jika sistem itu mudah digunakan, sedangkan persepsi kegunaan adalah kondisi dimana pengguna ingin mengunakan sistem jika berguna untuknya. Dengan kemudahan sistem yang dapat dipahami oleh pengguna maka timbul suatu keinginan untuk menggunakan sistem tersebut dan jika semakin sering menggunakan maka hal tersebut menunjukkan sistem tersebut bermanfaat, maka dapat dikatakan pengguna dapat menerima sistem tersebut (Abadi \& Latifah, 2016).

Dari penjelasan diatas maka penulis ingin mengetahui apakah sistem informasi pengolahan nilai menggunakan Kurikulum 2013 dapat diterima atau tidak untuk para guru, selain itu dengan menggunakan model TAM diharapkan dapat mengetahui apakah para guru memiliki keinginan untuk menggunakan sistem informasi pengolahan nilai dengan kurikulum 2013 dan apakah para guru memahami sistem dengan mudah.

\section{METODE PENELITIAN}

Metode penelitian merupakan cara ilmiah untuk mendapatkan data dengan tujuan dan kegunaan tertentu. Cara yang dilakukan pada penelitian ini dengan melakukan mencari, memperoleh, mengumpulkan dan mencatat data (Galih. Surono, 2020).

Untuk jenis penelitian yang digunakan adalah data kualitatif dan untuk mengumpulkan data pada penelitian ini meliputi observasi langsung pada objek penelitian, kemudian melakukan wawancara ke wali kelas dan studi literature (Tupan Tri M dan Irwansyah, 2020). 
Pada tahapan analisis data menggunakan model TAM, dimana model ini akan menjelaskan bagaimana tingkat kesiapan pengguna terhadap implementasi teknologi dalam suatu organisasi, selain itu model TAM dapat digunakan untuk mengetahui tingkat pengetahuan pengguna tentang teknologi informasi dimana pengguna merasakan kemudahan didalam memahami sistem aplikasi yang akan diimplementasikan. Dan untuk kegunaan suatu teknologi merupakan tujuan terakhir pengguna untuk menguasai komunikasi dan teknologi informasi (Sani et al., 2020).

Berikut ini adalah penjelasan lebih detail mengenai langkah - langkah penelitian yang dilakukan:

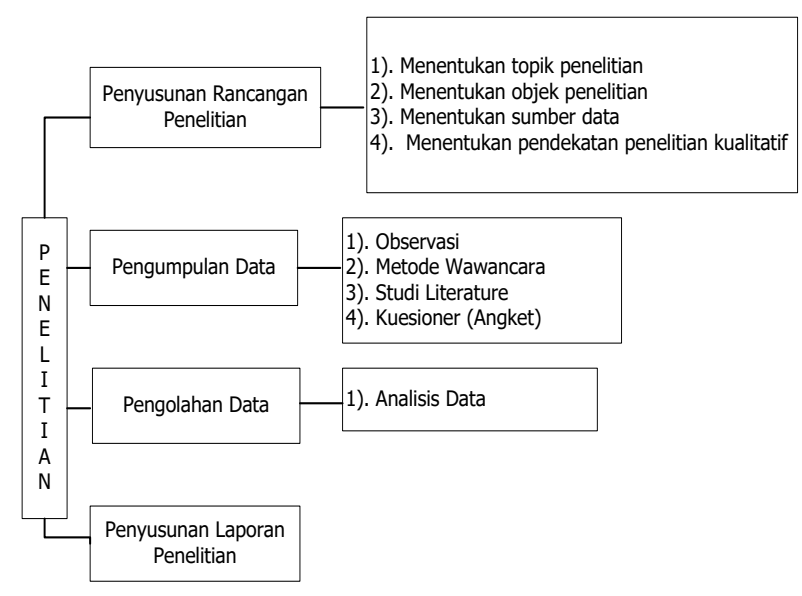

Sumber : (Pusparini et al., 2020)

Gambar 1 Langkah - langkah penelitian

Diawali dengan penyusunan rancangan penelitian yang dimulai dari menentukan topik penelitian, kemudian objek dan menentukan sumber data yang digunakan serta menentukan jenis datanya. Pengumpulan data dimulai dari observasi dengan melakukan pengamatan langsung ke objek penelitian, kemudia melakukan wawancara ke wali kelas, studi literature yaitu membaca jurnal, buku yang berkaitan dengan penelitian dan melakukan angket. Kemudian mengolah data dengan menganalisis data yang sudah diperoleh dengan menggunakan model TAM. Penyusunan laporan penelitian yang telah dilakukan.

\section{HASIL DAN PEMBAHASAN}

\section{Pengumpulan Data}

Pada tahapan ini dilakukan mengidentifikasi data yang sudah terkumpul berdasarkan hasil wawancara dan kuesioner.

\section{Analisis Pembahasan Masalah}

Pada penelitian ini membahas mengenai hasil evaluasi pengujian penggunaan metode TAM untuk sistem pengolahan nilai. Tujuan dari pengujian ini adalah untuk mengetahui apakah sistem (Wiliani et al., 2020).

Pertanyaan kuesioner yang dibuat berdasarkan 4 parameter dalam model TAM dengan menggunakan 11 responden dan 11 pertanyaan dimana 5 pertanyaan yang mengarah ke persepsi kemudahan, 5 pertanyaan pada persepsi kegunaan, 5 pertanyaan pada sikap penggunaan sistem dan 3 pertanyaan pada niat pengguna sistem (Setiawan, 2020).

Dalam memberikan jawaban dari kuesioner yang diberikan dibuat skala pengukuran sebagai berikut: (Nur Nawaningtyas Pusparini, 2020).

Tabel 1. Jawaban dan Skor

\begin{tabular}{cc}
\hline$\%$ Kategori & Keterangan \\
\hline $81 \%-100 \%$ & Sangat Setuju \\
$61 \%-80 \%$ & Setuju \\
$41 \%-60 \%$ & Netral \\
$21 \%-40 \%$ & Kurang Setuju \\
$0 \%-20 \%$ & Tidak Setuju \\
\hline \multicolumn{2}{l}{ Sumber : (Pusparini et al., 2020) }
\end{tabular}

Tabel 2. Skala Pengukuran

\begin{tabular}{clc}
\hline Indikator & \multicolumn{1}{c}{ Keterangan } & Bobot Nilai \\
\hline SS & Sangat Setuju & 5 \\
S & Setuju & 4 \\
CS & Cukup Setuju & 3 \\
TS & Tidak Setuju & 2 \\
STS & Sangat Tidak Setuju & 1 \\
\hline \multicolumn{2}{c}{ Sumber : (Pusparini et al., 2020) }
\end{tabular}

Berikut adalah hasil tanggapan respoden berdasarkan persepsi kegunaan dapat dilihat pada tabel berikut :

\section{Persepsi Kemudahan (Perceived Ease of Use)}

Tabel 3. Penilaian Aspek PEOU

\begin{tabular}{lccccccc}
\hline Jawaban & Bobot & $\mathbf{1}$ & $\mathbf{2}$ & $\mathbf{3}$ & $\mathbf{4}$ & $\mathbf{5}$ & Total \\
\hline SS & 5 & 0 & 0 & 0 & 0 & 1 & 1 \\
S & 4 & 5 & 2 & 7 & 5 & 2 & 21 \\
CS & 3 & 4 & 7 & 4 & 4 & 6 & 25 \\
TS & 2 & 2 & 2 & 0 & 2 & 2 & 8 \\
STS & 1 & 0 & 0 & 0 & 0 & 0 & 0 \\
Jumlah Responden & 11 & 11 & 11 & 11 & 11 & - \\
Skor Aktual & & 36 & 33 & 40 & 36 & 35 & 180 \\
Skor Ideal & & 55 & 55 & 55 & 55 & 55 & 275 \\
\hline
\end{tabular}

Sumber : (Pusparini et al., 2020) 
Tabel diatas adalah hasil penilaian aspek persepsi kemudahan dengan skor aktual sebagai berikut:

$$
\begin{aligned}
& \% \text { skor aktual }=\frac{\text { skor aktual PEOU }}{\text { skor Ideal PEOU }} \times 100 \% \ldots \\
& \% \text { skor aktual }=\frac{180}{275} \times 100 \%=65,45 \% \ldots \ldots \ldots
\end{aligned}
$$

\section{Persepsi Kegunaan (Perceived Usefulness)} Tabel 4. Penilaian Aspek PU

\begin{tabular}{lccccccc}
\hline Jawaban & Bobot & $\mathbf{1}$ & $\mathbf{2}$ & $\mathbf{3}$ & $\mathbf{4}$ & $\mathbf{5}$ & Total \\
\hline SS & 5 & 1 & 1 & 1 & 1 & 0 & 4 \\
S & 4 & 5 & 10 & 10 & 6 & 8 & 39 \\
CS & 3 & 5 & 0 & 0 & 4 & 1 & 10 \\
TS & 2 & 0 & 0 & 0 & 0 & 2 & 2 \\
STS & 1 & 0 & 0 & 0 & 0 & 0 & 0 \\
Jumlah Responden & 11 & 11 & 11 & 11 & 11 & - \\
Skor Aktual & 40 & 45 & 45 & 41 & 39 & 210 \\
Skor Ideal & 55 & 55 & 55 & 55 & 55 & 275 \\
\hline \multicolumn{5}{c}{ Sumber : (Pusparini et al., 2020) }
\end{tabular}

Tabel diatas adalah hasil penilaian aspek persepsi kegunaan dengan skor aktual sebagai berikut :

$$
\% \text { skor aktual }=\frac{210}{275} \times 100 \%=76,36 \%
$$

Persepsi Sikap Penggunaan Sistem (Attitute Toward using).

Tabel 5. Penilaian Aspek ATU

\begin{tabular}{clllllcc}
\hline Jawaban & Bobot & $\mathbf{1}$ & $\mathbf{2}$ & $\mathbf{3}$ & $\mathbf{4}$ & $\mathbf{5}$ & Total \\
\hline SS & 5 & 1 & 1 & 1 & 1 & 1 & 5 \\
S & 4 & 5 & 8 & 5 & 4 & 5 & 27 \\
CS & 3 & 5 & 2 & 5 & 4 & 2 & 18 \\
TS & 2 & 0 & 0 & 0 & 2 & 3 & 5 \\
STS & 1 & 0 & 0 & 0 & 0 & 0 & 0 \\
Jumlah Responden & 11 & 11 & 11 & 11 & 11 & - \\
Skor Aktual & 40 & 43 & 40 & 37 & 37 & 197 \\
Skor Ideal & 55 & 55 & 55 & 55 & 55 & 275 \\
\hline
\end{tabular}

Sumber : (Pusparini et al., 2020)

Tabel diatas adalah hasil penilaian aspek persepsi Sikap Penggunaan Sistem dengan skor aktual sebagai berikut :

$\%$ skor aktual $=\frac{197}{275} \times 100 \%=71,63 \%$
Persepsi Niat Penggunaan Sistem (Behavioral Intention To Use)

Tabel 6. Penilaian Aspek BIU

\begin{tabular}{lccccc}
\hline Jawaban & Bobot & $\mathbf{1}$ & $\mathbf{2}$ & $\mathbf{3}$ & Total \\
\hline SS & 5 & 1 & 2 & 1 & 4 \\
S & 4 & 7 & 9 & 0 & 16 \\
CS & 3 & 1 & 0 & 7 & 8 \\
TS & 2 & 2 & 0 & 3 & 5 \\
STS & 1 & 0 & 0 & 0 & 0 \\
Jumlah Responden & 11 & 11 & 11 & - \\
Skor Aktual & 40 & 46 & 32 & 118 \\
Skor Ideal & 55 & 55 & 55 & 165 \\
\hline \multicolumn{4}{r}{ Sumber : (Pusparini }
\end{tabular}

Tabel diatas adalah hasil penilaian aspek persepsi Niat Penggunaan Sistem dengan skor aktual sebagai berikut :

$\%$ skor aktual $=\frac{118}{165} \times 100 \%=71,15 \%$

Berdasarkan tingkat penggunaan sistem dapat di simpulkan sebagai berikut :

\begin{tabular}{|c|c|c|c|c|}
\hline No & $\begin{array}{c}\text { Kesimpulan } \\
\text { Pengujian }\end{array}$ & $\begin{array}{c}\text { Skor } \\
\text { Aktual }\end{array}$ & $\begin{array}{l}\text { Skor } \\
\text { Ideal }\end{array}$ & Jumlah \\
\hline 1 & $\begin{array}{l}\text { Persepsi } \\
\text { Kemudahan }\end{array}$ & 180 & 275 & $65,4 \%$ \\
\hline 2 & $\begin{array}{l}\text { Persepsi } \\
\text { Kegunaan }\end{array}$ & 210 & 275 & $76,3 \%$ \\
\hline 3 & $\begin{array}{l}\text { Sikap } \\
\text { Penggunaan } \\
\text { Sistem }\end{array}$ & 197 & 275 & $71,6 \%$ \\
\hline 4 & $\begin{array}{l}\text { Niat } \\
\text { Penggunaan } \\
\text { Sistem } \\
\text { TOTAL }\end{array}$ & 118 & 165 & $71,1 \%$ \\
\hline
\end{tabular}

Tabel 7. Kesimpulan Perhitungan Kuisoner dengan Metode TAM

Berdasarkan tabel diatas maka disimpulkan pengujian dengan penerimaan sistem dengan 4 (empat) aspek pengujian, didapat hasil Persepsi Kemudahan (Perceived Ease Of Use) sebesar 65,4\%, Persepsi Kegunaan (Perceived Uselfuness) sebesar 76,3\%,Sikap Penggunaan Sistem (Atitude Toward Using) sebesar $71,6 \%$ dan Niat Penggunaan Sistem (Behavioral Intention To Use) sebesar 71,1\%. 
Maka secara keseluruhan didapatkan rata-rata nilai pengujian penerimaan pengguna (user acceptance testing) dengan Metode Technology Acceptance Model (TAM) sebesar 71,21\% dan secara keseluruhan proses ini disetujui. Berikut ini adalah hasil analisis deskriptif berdasarkan 4 variabel metode TAM diantaranya:

Perceived Usefulness, berdasarkan hasil presentase jawaban responden sebesar 76,3\% menunjukkan pengguna percaya bahwa adanya sistem informasi pengolahan nilai dengan kurikulum 2013 dapat memberikan manfaat dan kegunaan dan ini masuk ke dalam kategori setuju.

Perceived Ease of Use, berdasarkan hasil presentase jawaban responden sebesar 65,4 \% menunjukkan pengguna merasa cukup meyakini bahwa sistem yang digunakan lebih mudah digunakan dan dioperasikan dan ini masuk ke dalam kategori setuju.

Attitude Toward Using, berdasarkan hasil presentase jawaban responden sebesar 71,6\% menunjukkan keingintahuan yang besar dari pengguna untuk menggunakan sistem dan ini masuk ke dalam kategori setuju.

Behavioral Intention To Use, berdasarkan hasil presentase dari jawaban responden yang sebesar $71,1 \%$ menunjukkan bahwa adanya keinginan untuk tetap menggunakan sistem dan ada keinginan untuk mempengaruhi pengguna lain untuk menggunakan sistem.

\section{KESIMPULAN}

Berdasarkan uraian diatas diperoleh kesimpulan bahwa metode TAM digunakan dengan tujuan Jadi dapat diartikan bahwa TAM merupakan model untuk mengukur faktor perilaku dari penerimaan teknologi, dimana yang pertama adalah persepsi kegunaan dan kedua adalah persepsi kemudahan penggunaan. Dan berdasarkan hasil pengujian diketahui Perceived Usefulness menunjukkan pengguna percaya bahwa adanya sistem informasi pengolahan nilai dapat memberikan manfaat dan kegunaan. Untuk Perceived Ease of Use, pengguna merasa cukup meyakini bahwa sistem yang digunakan lebih mudah digunakan dan dioperasikan. Attitude Toward Using, menunjukkan keingintahuan yang besar dari pengguna untuk menggunakan sistem dan behavioral Intention To Use, menunjukkan bahwa adanya keinginan untuk tetap menggunakan sistem dan ada keinginan untuk mempengaruhi pengguna lain untuk menggunakan sistem.

\section{DAFTAR PUSTAKA}

Abadi, S., \& Latifah, F. (2016). Decision Support System Penilaian Kinerja Karyawan Pada Perusahaan Menggunakan Metode Simple Additive Weighting. Jurnal TAM (Technology Acceptance Model), 6, 37-43.

Abidin, Z., Ardian, Y., Informasi, S., Malang, U. K., Informasi, S., \& Malang, U. K. (2013). Sistem Pendukung Keputusan Penilaian Siswa Berprestasi Kurikulum 2013 Berbasis Web Pada Smk Negeri 1 Gedangan Menggunakan Metode Saw.

Agus Budiyantara, Irwansyah, Egi Prengki, P. A. P. (2020). Komparasi Algoritma Decision Tree, Naive Bayes Dan K-Nearest Neighbor Untuk Memprediksi Mahasiswa Lulus Tepat Waktu.

Astuti, Y. P., Subhiyakto, E. R., \& Adi, P. W. (2019). Pendampingan Guru - Guru Dalam Pembuatan Raport Kurikulum 2013 Di Mi Miftahul Hidayah Gunungpati Semarang. Abdimasku: Jurnal Pengabdian Masyarakat, 2(2), 73. https://doi.org/10.33633/ja.v2i2.44

Galih. Surono, N. N. P. (2020). Journal of technology information. Http://Jurnal.Kampuswiduri.Ac.Id/, 5(1), 25-30.

Nur Nawaningtyas Pusparini, A. S. (2020). Mengukur Keberhasilan Penerapan Sistem Informasi Akademik Dengan Model Kesuksesan Delon And Mclean. Methomika, 4(2), 149-155.

Ramadhani, H., \& Monalisa, S. (2017). Analisis Penerapan Sistem Informasi Pengelolaan Nilai Raport Menggunakan Metode TAM. Jurnal Ilmiah Rekayasa Dan Manajemen Sistem Informasi, 3(2), 65-69.

Sani, A., Subiyakto, A., \& Khawa, T. (2020). Integration of the Technology Readiness and Adoption Models for Assessing IT Use among SMEs in Indonesia. September, 3107-3113. https://doi.org/10.5220/0009948131073113

Setiawan, W. (2020). Pemilihan Guru Terbaik, MPE, con Implementasi Metode Perbandingan Eksponensial (MPE) dalam Pemilihan Guru Terbaik di SMK XYZ. JATISI (Jurnal Teknik Informatika Dan Sistem Informasi), 6(2), 212228. https://doi.org/10.35957/jatisi.v6i2.216

Sujai, I., Purwanto, \& H.Himawan. (2016). Prediksi Hasil Penjurusan Siswa Sekolah Menengah Atas Dengan Menggunakan Algoritma Decision Tree C.4.5. 12(April), 42-53. 
Tupan Tri M dan Irwansyah. (2020). Implementasi Data Mining Untuk Menentukan Kelayakan Pemberian Kredit Dengan Menggunakan Algoritma K-Nearest Neighbors $(\mathrm{K}-\mathrm{Nn})$.

Ummi Khalifah, Nur Nawaningtyas Pusparini, O. K. (2020). Analisis Evaluasi Penerapan Sistem Informasi Pengolahan Nilai Pada Kurikulum 2013 Dengan Metode TAM.
Wiliani, N., Sani, A., Budiyantara, A., Haryanto, T., Manaf, K., \& Firmansyah, E. (2020). Influences of the Environmental Context on the Acceptance and Adoption Technology among SMEs in Indonesia Esa Firmansyah Sekolah Tinggi Manajemen Informatika dan Komputer (STMIK) Sumedang Influences of the Environmental Context on the Acceptance and Adopt. June. 